Katarzyna Morena

Uniwersytet Pedagogiczny im. KEN w Krakowie

elc@elc-krakow.pl

\title{
FOREIGN LANGUAGE ANXIETY IN OUT-OF-CLASS PERFORMANCE. IDENTIFYING LANGUAGE-ANXIETY SOURCES, ITS EFFECTS, AND COPING STRATEGIES
}

\begin{abstract}
Language researchers have long been aware that anxiety can be associated with the language learning process and negatively correlate with academic achievement, motivation and successful oral performance. Foreign language anxiety was first defined as a negative feeling associated with a language classroom and resulting from a fear of negative evaluation, tests and communication apprehension (Horwitz and Young, 1991). Some learners also reported that they experienced language anxiety in out-of-class oral performance, that it negatively affected their feeling of competence, and beliefs about their successful language acquisition, and also triggered physiological and cognitive responses. The research aimed at identifying sources of language anxiety and its manifestations in adult EFL learners in out-of-class settings, and a set of six strategies was proposed to help learners mitigate the feeling of foreign language anxiety.
\end{abstract}

Keywords: foreign language anxiety, adult learners, out-of-class performance, coping strategies

Słowa kluczowe: lęk językowy, osoby dorosłe uczące się języków obcych, stosowanie języka obcego poza klasą, strategie radzenia sobie z lękiem językowym 


\section{Introduction}

\subsection{Who are adult learners?}

According to Rogers (2007: 8), adults are "people who have acquired the status of maturity in their own eyes as partners, friends, employers and employees". Maturity involves having legal and social responsibilities such as voting, a driving licence, fighting for your country, and possessing property (Rogers, 2008).

In educational settings, adult learners usually attend courses as an extension or continuation of their studies (e.g. as part of life-long learning) and have well-defined goals and motivation. These learners study to enhance their professional skills, and to be in a better position to meet the demands of work and the job market, born of a willingness to travel or to treat study as an integral part of their personal development.

They also hold certain beliefs and expectations about language learning. Many adults envisage learning as quick and effective and hope to contribute to the learning process with their experience and knowledge (Rogers, 2008). However, as adults they have some well-developed ideas about life, and often admitting they need to learn something, is like admitting there is something wrong with their present system (Rogers, 2007). Their beliefs and attitudes are formed in their prior learning experiences. Some adult learners believe that it is better to say nothing in a second language unless it is said correctly (Horwitz and Young, 1991). Others tend to believe they would never acquire language at the desired level (often as compared to younger learners) and as a result develop a negative perception of their own intellectual competence (Onwuegbuzie et al., 1997). Adults in particular perceive themselves as "intelligent, socially adept individuals" (Horwitz and Young, 1991: 31), however, this perception can be questioned due to limited competence in L2. "You feel frustrated because you're an interesting adult and you sound like a babbling baby" (Price, 1991: 105). Therefore, prior-history, age stereotype, beliefs about language learning and self-perception can be found to be predictors of language anxiety.

\subsection{Anxiety}

The main difficulty in defining the term anxiety results from the lack of agreement over its causes, measurement and treatment (Sarason, 1988). Spielberger (1972: 19) defines anxiety as "an unpleasant emotional state or condition which is characterised by subjective feelings of tension, apprehension and worry, and by the activation or arousal of the automatic nervous system that accompanies these feelings". Anxiety is said to consist of physiological, 
Foreign language anxiety in out-of-class performance. Identifying...

behavioural, and cognitive (Vasa and Pine, 2004) and emotional components (Seligman, Walker and Rosenhan, 2001). Some examples are shown in Table 1.

\begin{tabular}{|l|l|l|l|}
\hline \multicolumn{4}{|c|}{ Anxiety components } \\
\hline \multicolumn{1}{|c|}{ Physiological } & \multicolumn{1}{|c|}{ Emotional } & \multicolumn{1}{|c|}{ Behavioural } & \multicolumn{1}{c|}{ Cognitive } \\
\hline $\begin{array}{l}\text { Increased heart rate, in- } \\
\text { creased blood pressure, } \\
\text { muscle tension, }\end{array}$ & Feeling of panic & $\begin{array}{l}\text { Avoidance behaviour: } \\
\text { sweaty palms }\end{array}$ & $\begin{array}{l}\text { Missing lessons, } \\
\text { postponing homework, mind going } \\
\text { blank, inability to utter a } \\
\text { over-studying, } \\
\text { word, inability to under- } \\
\text { stand when spoken to, } \\
\text { stammering, } \\
\text { fidgeting }\end{array}$ \\
& & threatening \\
\hline
\end{tabular}

Table 1: The physiological, motional, behavioural and cognitive components of anxiety.

The latest approaches to anxiety additionally distinguish between fear and anxiety. Although they co-exist, the basic difference lies in the direction of defensive behaviour. Fear makes organisms move away from danger, while anxiety makes them move towards the danger, or avoid facing dangerous situations. These kinds of behaviour are also known as fleeing (active avoidance) or fighting (active approaching), along with freezing (passive avoidance) (Piechurska-Kuciel, 2008).

According to Maclntyre (1995), the cognitive perspective is relevant to the study of language anxiety because it can provide an explanation of the negative effects that anxiety can have on language learning.

\subsection{A typology of anxiety}

There are various kinds of anxiety, depending on the perspective adopted in the research on anxiety. Dornyei (2005: 198) asserts that "anxiety is usually not seen as a unitary factor but a complex made up of constituents that have different characteristics". For the purposes of this article only trait vs. state anxiety and performance anxiety will be discussed.

According to Spielberger (1983), state anxiety is moment-to-moment experience, a transitory condition which fluctuates over time, in which people are sensitive to how others appraise them. It is usually experienced before an evaluative situation such as a test, speaking publicly, or trying to communicate in a foreign language. However, trait anxiety is viewed as the predisposition of a person to become nervous in many situations, and is considered to impair the person's cognitive functioning, disturb the memory, or lead to avoidance behaviour. What is more, individuals with a high level of trait anxiety perceive the world as threatening.

Performance anxiety occurs when individuals find themselves in a performance-based situation and in anticipation of performing, and think of the possible negative evaluation of their performance (Piechurska-Kuciel, 2008). It 
comprises stage fright, communication apprehension and test anxiety. Daly (1991) asserts that fear of public speaking related to stage fright, can be stronger than phobias such as fear of snakes, heights or lifts. People who suffer from stage-fright can become self-conscious and focus on distractive internal bodily feelings such as sweating, butterflies in the stomach, and clammy hands, and apprise their own performance as negative. Communication apprehension occurs when individuals are in fear of oral communication with other people (Daly, 1991), and, as a result, try to avoid or withdraw from it. Apprehension was found to positively correlate with low self-esteem, intolerance of ambiguity, and test anxiety (Daly, 1991). Tests can be highly anxiety-provoking due to their evaluative nature, and anxious learners perceive tests as threatening, with the consequence that they can perform poorly (Piechurska-Kuciel, 2008).

\subsection{Language anxiety and its sources}

Foreign language anxiety was defined by Horwitz and Young (1991: 31) as "a distinct complex of self-perceptions, beliefs, feelings and behaviour related to

\begin{tabular}{|l|l|}
\hline \multicolumn{1}{|c|}{ Some of the sources of language anxiety (LA) } & \multicolumn{1}{|c|}{ Other researchers } \\
\hline $\begin{array}{l}\text { 1. Teacher's attitude and classroom procedures } \\
\text { The teacher in the role of a drill sergeant, fast-paced lessons, no time to answer } \\
\text { questions, error correction (records from students about correction proce- } \\
\text { dures) - embarrassing, reprimanding, ridiculing. }\end{array}$ & $\begin{array}{l}\text { Young (1991), } \\
\text { Von Worde (2003), } \\
\text { Price (1991), } \\
\text { Turula (2002) }\end{array}$ \\
\hline $\begin{array}{l}\text { 2. Learner's beliefs } \\
\text { Language learning requires a special aptitude, and students must develop an } \\
\text { excellent accent and correct pronunciation, accuracy over fluency, and learner } \\
\text { beliefs that age is an obstacle to learning a foreign language }\end{array}$ & $\begin{array}{l}\text { Young (1991), } \\
\text { Horwitz and Young } \\
\text { (1991), }\end{array}$ \\
\hline $\begin{array}{l}\text { 3. Speaking in front of others } \\
\text { Adult learners worry about losing face, making errors in front of others, com- } \\
\text { municating effectively and pronouncing correctly, and having the right intona- }\end{array}$ \\
tion, and they become self-conscious, and worry that native speakers might \\
not understand them & $\begin{array}{l}\text { Price (1991), } \\
\text { Young (1991), }\end{array}$ \\
\hline $\begin{array}{l}\text { 4. Perceived lack of proficiency } \\
\text { Anxiety is associated with lack of proficiency or knowledge, unpreparedness, } \\
\text { the inability to retrieve appropriate words and expressions, inability to express } \\
\text { oneself, and not being able to understand when spoken to, might lead to LA. }\end{array}$ & $\begin{array}{l}\text { Woodrow (2006, } \\
\text { Morena (2015) }\end{array}$ \\
\hline $\begin{array}{l}\text { 5. Evaluation, novelty, prior history } \\
\text { Tests, ridiculing error correction, novelty, unfamiliar problems, a new environ- } \\
\text { ment where everybody focuses on you, negative experiences from the lan- } \\
\text { guage-learning situation }\end{array}$ & Woodrow (2006), \\
\hline
\end{tabular}

Table 2: Some common sources of language anxiety.

classroom language learning arising from the uniqueness of the languagelearning process". Drawing on their own and previous research, Horwitz and 
Young (1991) assert that language anxiety is related to performance in academic and social contexts, and primarily comprises three elements - communication apprehension, test anxiety and fear of negative evaluation.

Language anxiety was found be triggered by a variety of situations, e.g. classroom procedures, learners' erroneous beliefs, performing in public, perceived lack of proficiency, prior history and competitiveness (Young, 1991, Daly, 1991, Von Worde, 2003, Ohata, 2005). Some studies on the sources of language anxiety are shown in Table 2 . Language anxiety also correlated negatively with the input, processing and output stages of language acquisition (Maclntyre and Gardner, 1994), and had a negative effect on academic achievements, reflected in physical and behavioural reactions, and had negative personal and social consequences (c.f. Table 3).

\subsection{The effects of language anxiety}

Experiencing language anxiety can lead to cognitive and academic, physical, behavioural, social and personal consequences. Table 3 depicts some common effects of language anxiety identified in previous research.

\begin{tabular}{|c|c|c|}
\hline Cognitive and academic & Physical and behavioural & Social and personal \\
\hline $\begin{array}{l}\text { Negative effects on input-processing-output } \\
\text { (Maclntyre and Gardner, 1994); } \\
\text { inability to utter a word, mind going blank, } \\
\text { problems with understanding when spoken } \\
\text { to (Morena, 2015); } \\
\text { low-academic-achievement learners have } \\
\text { lower grades, make more mistakes, } \\
\text { take more time on tests; anxious learners } \\
\text { communicate less information in a less- pro- } \\
\text { ficient manner, (Maclntyre and Gardner, } \\
\text { 1991, Horwitz and Young, 1991) }\end{array}$ & $\begin{array}{l}\text { Clammy hands, sweating, pounding heart, } \\
\text { tapping foot, drumming on the desk (Von } \\
\text { Worde, 2003) } \\
\text { playing with hair or other objects, nervous } \\
\text { laughter; avoidance behavior - not showing } \\
\text { up for the lesson, remaining silent, avoiding } \\
\text { eye contact, withdrawing from the course } \\
\text { (Scovel, 1991) }\end{array}$ & $\begin{array}{l}\text { Less willing to communicate (Maclntyre, 1999); } \\
\text { in job interviews apprehensive candidates per- } \\
\text { ceived as less positive, offered lower salaries, } \\
\text { climb career ladder less quickly; low self-confi- } \\
\text { dence, and low self-esteem, less innovative } \\
\text { (Daly, 1991) }\end{array}$ \\
\hline
\end{tabular}

Table 3: Some common effects of language anxiety.

According to Maclnyre and Gardner (1994), anxiety can negatively affect the input stage (encoding), processing (organising) and output (retrieving). In the input stage a learner creates the first representations in the memory. Anxious learners were found to have a mental block, and fail to take in material or comprehend it, and as a consequence language acquisition did not progress. At the processing stage, cognitive operations such as the organisation, storage and assimilation of the material take place. Anxious learners might take more time to process, understand and learn new things, such as vocabulary. The output stage involves the production of previously learned material. Anxiety was found to negatively affect the production of language and the speed of retrieval (Maclnyre and 
Gardner, 1994). Some anxious learners can experience "freezing" on tests, or while communicating, and therefore their performance might not reflect their competence (Horwitz and Young, 1991).

In summary, various studies have shown that language anxiety can be associated with classroom procedures, the evaluative nature of the learning environment, perceived lack of competence when compared to others, and learners' beliefs concerning age and acquisition, accuracy and fluency. Most studies were confined to language learning environments such as school. There is, however, little research on language anxiety experienced outside formal settings. This study attempted to fill the gap. In addition, some strategies designed to mitigate the feeling of language anxiety were applied and tested for their effectiveness.

\section{The study}

The aim of the study was to a) identify sources of language-anxiety and the effects of out-of-class performance among EFL adult learners, and b) investigate the effectiveness of language-anxiety-coping strategies. This type of research is called action research, as it possesses three characteristics listed by Kemmis and McTaggart (1988). Firstly, it is carried out by practitioners (i.e. teachers) rather than outside researchers; secondly, it is collaborative; and thirdly, it is aimed at changing things. Cohen et al. (2007) pointed to the situational nature of action research, which is concerned with the identification and solution of problems in specific contexts.

\subsection{The participants}

56 adult learners of English as a foreign language participated in the study. The sample consisted of 39 females $(n=39)$ and 17 males $(n=17)$. The average time spent learning English was 11 years $(S D=8.04)$.

All respondents were students at a private school of English, and attended lessons individually or in small groups. They used English for work-related purposes such as negotiations, preparing and delivering presentations, interviews, communication with foreign colleagues and branches, and business and leisure travel.

\subsection{Tools and procedures}

The study consisted of three phases. Firstly, the sources and effects of language anxiety were detected by applying Studenska's (2007) Foreign Lan- 
guage Anxiety Inventory (FLAI). Secondly, a set of coping strategies were offered to participants, based on results obtained from the FLAI. Finally, the learners were asked to evaluate these strategies in terms of their effectiveness and say whether they would use them in the future.

\subsubsection{Foreign Language Anxiety Inventory}

In order to identify the sources and effects of language anxiety, a shortened version of Foreign Language Anxiety Inventory (FLAI) (Studenska, 2007) was used for the purposes of the study. It consisted of 50 items, each marked on a 5-point Likert scale, ranging from 1 (very rarely) to 5 (very often). 10 items related to classroom procedures were removed from the original 60 -item Studenska's FLAI (2007) - e.g. I am afraid to attend my foreign language class because of the nervous atmosphere created by the teacher (item 4), or Foreign language lessons are stressful for me, and that is why I quit them or miss part of them (item 40) - as the research focus was on out-of-class experience of language anxiety. Some items were also reworded, e.g. 'test' situation to 'evaluation situation', 'what to learn' was changed to 'how to prepare.'

Similarly to the FLAl, the items were grouped under 5 factors: speaking and self-image (F1, 19 items), a formal evaluation of foreign language proficiency (F2, 4 items), feeling incompetent (F3, 13 items), avoidance behaviour (F4, 4 items) and physiological and cognitive reactions (F5, 10 items). Originally, Factor 4 was labelled as 'the avoidance of learning' and Factor 5 'physiological reactions together with nervous behaviour'. However, as the participants attended the courses voluntarily and were highly motivated to learn, the name of Factor 4 was changed to 'avoidance behaviour', which was related to reported instances of the avoidance of contact with native speakers of English or the use of excuses not to speak English. Furthermore, as the questionnaire included items describing cognitive reactions (mind going blank, forgetting the material), the Factor 5 group was called 'physiological and cognitive reactions', which was congruent with past research on the effects of language anxiety (e.g. Maclntyre and Gardner, 1994; Von Worde, 2003; Ohata, 2005).

\subsubsection{Coping strategies}

Six strategies were proposed for anxious learners.

The first strategy, called Accepting errors, was based on Crookall and Oxford (1991) - the Mistakes Panel and Speaking with Errors - both activities "encouraging learners to take an amusing look at errors, and realise they are not taboo, and that they can contribute to learning" (Crookall and Oxford, 
1991: 147). The second strategy aimed at Changing learner beliefs. It consisted of activities restructuring negative beliefs related to age and learning, as well as supporting the strategy with selected examples of research in this area.

The third strategy was Learning conversation functions, following Mejias et al.'s (1991) assertion that explicit skills training and developing learners' speaking repertoires in oral situations should reduce their anxiety. The fourth strategy called Agony aunt - related to popular-magazine help columns, where people describe their problems and receive answers to them. It took the form of a blog. This strategy engaged participants in helping each other with the problem of experienced anxiety, aimed to develop a sense of community, and, as Crookall and Oxford (1991) stated, encourage learners to try to overcome the problem together.

The fifth strategy - Preparing presentations - consisted in training presentation skills, providing learners with presentation guidelines, and advice on how to deal with feelings of anxiety experienced prior to a presentation. The sixth strategy - Visualising - consisted of guiding learners through images related to anxiety-triggering situations from the least to the most anxiety-provoking, and showing them managing the situations successfully. This technique which uses visualisation to reduce phobias, fear, tension and various types of anxiety, is called systematic desensitisation (Arnold, 2005: 273).

\subsubsection{Evaluation questionnaire}

At the end of the strategy training, participants were asked to evaluate each strategy they had practised, and to answer two questions: How effective was each strategy in your personal case? Responses were recorded as 1 - not effective at all, 2 - effective, 3 - very effective; and Will you use strategic skills in the future? Responses: $1-$ I will not use them, 2 - maybe I will use them, and $3-$ I will certainly us them.

\section{Results}

Firstly, an exploratory analysis of a shortened version of the FLAI was conducted. Secondly, a frequency of occurrence analysis for each item was applied in order to identify the sources and effects of language anxiety in the sample. Thirdly, a strategy evaluation questionnaire was analysed.

\subsection{Foreign language anxiety analysis}

Table 4 shows descriptive statistics for the mean values for each of the questions and a question concerning total learning time. Due to the absence of a 
Foreign language anxiety in out-of-class performance. Identifying...

normal distribution for Factor 4 and the number of years of learning, the median value was applied.

\begin{tabular}{|l|c|c|c|c|c|c|}
\hline \multicolumn{1}{|c|}{ Factors } & $\mathrm{N}$ & Mean & Median & Min & Max & SD \\
\hline Factor 1 (speaking and self-image) & 56 & 47.30 & 48.50 & 18.00 & 68.00 & 10.61 \\
\hline Factor 2 (formal evaluation of foreign language proficiency) & 54 & 10.46 & 10.00 & 5.00 & 19.00 & 2.75 \\
\hline Factor 3 (feeling incompetent) & 54 & 41.52 & 42.00 & 16.00 & 60.00 & 8.08 \\
\hline Factor 4 (avoidance behaviour) & 56 & 5.21 & 5.00 & 2.00 & 10.00 & 1.63 \\
\hline Factor 5 (physiological and cognitive reactions) & 52 & 39.27 & 39.00 & 18.00 & 56.00 & 8.61 \\
\hline How many years have you been learning English ? & 56 & 11.80 & 11.00 & 1.00 & 44.00 & 8.04 \\
\hline
\end{tabular}

Table 4: Descriptive statistics for a modified version of the FLAI (Studenska, 2007).

An analysis of the frequency of occurrence for each answer from the FLAI on a 5-item Likert scale indicated that the participants very often felt self-conscious when they had to perform in front of a group (39.28\%) (cf. Table 5), and anxious when they had to speak English in front of the group of people $(23,21 \%)$. They often experienced language-related anxiety when had to speak about unfamiliar topics in English (37.50\%), speak English on the phone (35.71\%), feared making errors (33.92\%), and speak with native speakers of English (32.14\%).

\begin{tabular}{|l|c|c|c|c|}
\hline \multirow{2}{*}{$\begin{array}{l}\text { Factor 1 } \\
\text { (speaking and self-image) }\end{array}$} & \multicolumn{4}{|l|}{\begin{tabular}{l}
\multicolumn{4}{l|}{ "Irequency table: item 50: } \\
"I feel self-conscious when speaking English in front of a group of people".
\end{tabular}} \\
\cline { 2 - 5 } & $\mathrm{N}$ & Cum. number & Percent & Cum. percent \\
\hline Very rarely & 1 & 1 & 1.78 & 1.78 \\
\hline Rarely & 3 & 4 & 5.35 & 7.14 \\
\hline Sometimes & 11 & 15 & 19.64 & 26.78 \\
\hline Often & 19 & 34 & 33.92 & 60.71 \\
\hline Very often & 22 & 56 & 39.28 & 100.00 \\
\hline
\end{tabular}

Table 5: Frequency table for item 50 "I feel self-conscious when speaking English in front of a group of people".

What is more, language anxiety was often associated with beliefs that others spoke English better (53.57\%) (cf. Table 6). The participants very often felt they frequently used too-simple words and constructions in English, although they knew better ones (33.28\%).

\begin{tabular}{|l|c|c|c|c|}
\hline \multirow{2}{*}{$\begin{array}{l}\text { Factor } 2 \\
\text { (formal evaluation of foreign language }\end{array}$} & \multicolumn{4}{|l|}{$\begin{array}{l}\text { Frequency table: item 2: } \\
\text { "II keep thinking that others speak English better than / do". }\end{array}$} \\
\cline { 2 - 5 } & $\mathrm{N}$ & Cum. number & Percent & Cum. percent \\
\hline Sometimes & 10 & 10 & 17.85 & 17.85 \\
\hline Often & 30 & 40 & 53.57 & 71.42 \\
\hline Very often & 16 & 56 & 28.57 & 100.00 \\
\hline
\end{tabular}

Table 6: Frequency table for item 2 "I keep thinking that others speak English better than I do". 
Language anxiety was found to be associated with the feeling of incompetence and belief that participants would never learn English at a desired level (35.71\%), and they needed more time to learn English than the young (33.92\%). They also felt they were not able to show their real value when speaking English (35.71\%) (cf. Table 7).

\begin{tabular}{|l|c|c|c|c|}
\hline \multirow{2}{*}{$\begin{array}{l}\text { Factor 3 } \\
\text { (feeling } \\
\text { incompetent) }\end{array}$} & \multicolumn{4}{|l|}{$\begin{array}{l}\text { Frequency table: item 45. } \\
\text { "I am afraid to speak English because I know I am not able to show my real value". }\end{array}$} \\
\cline { 2 - 5 } & $\mathrm{N}$ & Cum. number & Percent & Cum. percent \\
\hline Very rarely & 5 & 5 & 8.92 & 8.92 \\
\hline Rarely & 12 & 17 & 21.42 & 30.35 \\
\hline Sometimes & 14 & 31 & 25.00 & 55.35 \\
\hline Often & 20 & 51 & 35.71 & 91.07 \\
\hline Very often & 5 & 56 & 8.92 & 100.00 \\
\hline
\end{tabular}

Table 7: Frequency table for item 45"I am afraid to speak English because I know I am not able to show my real value".

As far as avoidance behaviours are concerned, the participants indicated they often avoided joining discussions in English by nodding the head and smiling (37.50\%), or were afraid to initiate a conversation in English (26.78\%).

Finally, language anxiety was found to cause cognitive and physiological reactions such as mind going blank when they had to say something in English (40\%) and feeling nervousness (33.33\%) (cf. Table 8).

\begin{tabular}{|l|c|c|c|c|}
\hline \multirow{2}{*}{$\begin{array}{l}\text { Factor 5 } \\
\text { (physiological and } \\
\text { cognitive reactions) }\end{array}$} & \multicolumn{4}{|l|}{$\begin{array}{l}\text { Frequency table: item 31. } \\
\text { "When I have to say something in English my mind goes blank English". }\end{array}$} \\
\cline { 2 - 5 } & $\mathrm{N}$ & Cum. number & Percent & Cum. percent \\
\hline Very rarely & 4 & 4 & 7.27 & 7.27 \\
\hline Rarely & 13 & 17 & 23.63 & 30.90 \\
\hline Sometimes & 22 & 39 & 40.00 & 70.90 \\
\hline Often & 11 & 50 & 20.00 & 90.90 \\
\hline Very often & 5 & 55 & 9.09 & 100.00 \\
\hline
\end{tabular}

Table 8: Frequency table for item 3 "I get nervous when I have to present something in English".

The results obtained from the study showed that foreign language anxiety was associated with performing in front of others, fear of making errors, negative evaluation of language proficiency, inability to show one's real value in English, negative beliefs concerning age and language attainment. In turn, language anxiety triggered nervous feelings, avoidance behaviour and cognitive reactions in participants.

The next step in the action research was to offer learners exercises and strategies aimed at mitigating the feeling of language anxiety. 


\subsection{Strategy training}

Ten participants $(n=10)$ volunteered to take part in strategy training. It lasted for a period of three months and took place before or after their regular lessons. An unequal number of participants attended the selected strategy training: Accepting errors $(n=9)$, Changing beliefs $(n=7)$, Conversation functions $(n=10), A g$ ony Aunt $(n=8)$, Preparing presentations $(n=7)$, and Visualisation $(n=6)$.

\subsection{The evaluation questionnaire}

At the end of the strategy training, the participants evaluated each strategy in terms of its effectiveness and future use in mitigating language anxiety. Table 9 shows the assessment of the strategies' effectiveness and Table 10 the future use of learnt strategies (\% of $n$ ).

\begin{tabular}{|l|c|c|c|c|}
\hline \multicolumn{1}{|c|}{ Strategy } & Not effective at all & Effective & Very effective & $\mathrm{N}$ \\
\hline Accepting errors & 0.00 & 66.7 & 33.33 & 9 \\
\hline Changing beliefs & 14.29 & 14.29 & 71.42 & 7 \\
\hline Conversation functions & 0.00 & 50 & 50 & 10 \\
\hline Agony aunt & 0.00 & 75 & 25 & 8 \\
\hline Preparing presentations & 0.00 & 28 & 72 & 7 \\
\hline Visualisation & 0.00 & 50 & 50 & 6 \\
\hline
\end{tabular}

Table 9. Claimed effectiveness of mitigating strategies (\% of $\mathrm{n}$ ).

\begin{tabular}{|l|c|c|c|c|}
\hline & I will not use & Maybe I will use & I will certainly use & $\mathrm{N}$ \\
\hline Accepting errors & 11.10 & 66.7 & 22.22 & 9 \\
\hline Changing beliefs & 0.00 & 71.43 & 28.57 & 7 \\
\hline Conversation functions & 10 & 40 & 50 & 10 \\
\hline Agony aunt & 37.50 & 25 & 37.50 & 8 \\
\hline Preparing presentations & 0.00 & 28.57 & 71.43 & 7 \\
\hline Visualisation & 0.00 & 50 & 50 & 6 \\
\hline
\end{tabular}

Table 10: Claimed future use of mitigating strategies in percentage terms.

The participants claimed that the accepting-errors strategy $(n=9)$ was effective $(66 \%)$ or very effective $(33 \%)$ in coping with language anxiety and they maybe use it $(66 \%)$ or definitely use it $(22 \%)$ in the future. As far as the changing-learner-beliefs strategy $(n=7)$ is concerned, the majority of participants considered it very effective, and said they would possibly (71\%) or certainly (28\%) use the knowledge gained from this strategy in the future. As regards the learning-conversational-functions strategy, half the respondents $(n=5)$ marked it as very effective and the same number said they would use it in the future. The results obtained from the Agony aunt strategy $(n=8)$ showed 
that the majority found it effective (75\%), however the same number of participants $(37,5 \%)$ declared they would use it or not use it in the future. As far as the preparing presentations strategy $(n=7)$ is concerned, most subjects perceived it as very effective. The future use of skills acquired from this strategy was affirmed by 5 participants. When it comes to the visualisation strategy $(n=6)$, an equal number of participants found it effective and very effective respectively. When participants were asked whether they would use the visualisation strategy in the future, 3 of them responded "certainly they would." It should be noted that as the training group was small and the results of the assessment were self-reported, generalisations cannot be made.

\section{Discussion}

Language anxiety was found to stem from situations in which learners have to perform in front of other people. Adults might fear losing face as a result of the lack of language competence and the inability to show their real value to the public and their audience. Language anxiety emerges when people realise they have limited knowledge and competence in the $\mathrm{FL}$ (Young, 1991) or when they compare themselves with others. Adults tend to worry about the fact that they do not have adequate language resources to communicate effectively (Woodrow, 2006) and so developing their oral functional language, and behavioural skills required for success in a communicative context, might be helpful in reducing their anxiety (Mejias et al., 1991). Some learners worry about speaking with errors, and fear others will notice them.

The fear of making errors (F1) can result from prior negative school experiences, where more emphasis was put on accuracy than fluency. Adult learners often shared anecdotes from school on unpleasant error-correction techniques, which resulted in being convinced that they were unable to use the foreign language effectively. Other studies confirm the premise that explicit, mocking and ridiculing error correction in L2 can lead to anxious feelings (Young, 1991; Turula, 2002; Von Worde, 2003) and fear of errors (Price, 1991; Young, 1991; Ohata, 2005; Woodrow, 2006; Morena, 2015). Learners who become familiarised with errors reported the effectiveness of this strategy in dismissing their fear of errors.

Adult learners also hold certain beliefs about language learning, such as that they need more time to reach the desired level (Onwuegbuzie, Bailey and Daley, 1997), e.g. "I feel need more time to learn English than the young " or "I will never learn English well enough". Such perceptions can trigger anxious feelings and cause people to be less willing to communicate (Maclntyre, 1999) or lead to avoidance behaviour. Some participants reported they often avoided joining discussions in English by nodding their head and smiling, or that they 
were afraid to initiate a conversation in English. Therefore, helping learners to reformulate their negative perceptions and beliefs, and develop more positive self-talk can boost their self-esteem (Mejias et al., 1991) and lessen anxiety. Furthermore, dealing with anxiety in a direct way (e.g. Agony Aunt) as well as encouraging learners to collaborate to overcome the problem together might be effective ways of mitigating anxious feelings (Crookall and Oxford, 1991).

The participants reported cognitive reactions due to anxious feelings (F5), such as the use of simplified language or mind going blank. These findings are congruent with Maclntyre and Gardner's (1994) argument that language anxiety can have a negative effect on the performance stages, i.e. input, processing and output. In this light, mental techniques such as visualising and relaxation might be applied in order to evoke positive images about their performance and its outcome (Arnold, 2005).

\section{Conclusions}

Language anxiety has been mainly discussed from the perspective of the classroom situation. There has been little research into the relationship between adult learners and language anxiety in out-of-class performance. Although both settings share some similarities in that language anxiety can be associated with critical appraisal and a perceived lack of competence in the learner, the out-of-class experience of language anxiety poses other challenges for adult learners. Inability to show one's true merit in social/work situations can have personal consequences such as low self-esteem and self-confidence. It may decrease the possibility of rapid career advancement, cause withdrawal from interactions in a foreign language, and negatively affect motivation to continue learning languages.

Although, this study has limitations and its findings cannot be generalized to the whole population, it can be used as a guide for professionals working with adult learners. The study could also be complemented by qualitative investigation into strategies adults employ when facing language-related anxiety. Further research will focus on improving some of the sections of the FLAl to apply it to out-of-class contexts.

\section{BIBLIOGRAPHY}

Arnold, J. 2005. "Visualization: language learning with the mind's eye". (in) Affect in Language Learning. (ed. Arnold, J.). New York: Cambridge University Press: 260-278. Cohen, A., L. Manion and Morrison, K. 2007. Research Methods in Education. London: Routledge. 
Crookall, D. and Oxford, R. 1991. "Dealing with anxiety: Some practical activities for language learners and teacher trainees". (in) Language Anxiety: From Theory and Research to Classroom Implications. (eds. Horwitz, E.K. and Young, D.J.). Upper Saddle River: Prentice Hall: 141-150.

Daly, J. 1991. "Understanding communication apprehension: An introduction for language educators". (in) Language Anxiety: From Theory and Research to Classroom Implications. (eds. Horwitz, E.K. and Young, D.J.). Upper Saddle River: Prentice Hall: 3-13.

Dornyei, Z. 2005. The Psychology of the Language Learner: Individual Differences in Second Language Acquisition. Mahwah, New Jersey: LEA.

Horwitz, E.K. and Young, D.J. (eds.). 1991. Language Anxiety: From Theory and Research to Classroom Implications. Upper Saddle River: Prentice Hall.

Kemmis, S. and McTaggart, R. (eds.). 1988. The Action Research Planner. Geelong: Deakin University Press.

MacIntyre, P.D. and Gardner, R.C. 1991. "Language Anxiety: Its relationship to other anxieties and to processing in native and second languages". Language Learning, 41: 513-534.

MacIntyre, P.D. and Gardner, R.C. 1994. "The subtle effects of language anxiety on cognitive processing in the second language". Language Learning, 44: 283-305.

Maclntyre, P.D. 1995. "How does anxiety affect second language learning? A reply to Sparks and Ganschow". The Modern Language Journal, 79: 90-99.

MacIntyre, P.D. 1999. "Language anxiety: A review of the research for language teachers". (in) Affect in Foreign-Language and Second Language Learning: A Practical Guide to Creating a Low-Anxiety Classroom Atmosphere. (ed. Young, D.J.). Boston: McGraw-Hill College: 24-45.

Mejias, H., Applbaum, R.L., Applbaum, S.J. and Trotter II, R.T. 1991. "Oral- communication apprehension and Hispanics: An exploration of oral communication apprehension among Mexican American students in Texas". (in) Language Anxiety: From Theory and Research to Classroom Implications. (eds. Horwitz, E.K. and Young, D.J.). Upper Saddle River: Prentice Hall: 87-97.

Morena, K. 2015. "Foreign language anxiety and adult EFL learners: Sources, effects, and what can be done about it". (in) 10th IPB Erasmus Week Teaching Crossroads. (eds. Silva, E., Pais, C. and Pais, L.S.). Portugal: Instituto Politécnico da Bragança: 57-71.

Ohata, K. 2005. "Potential sources of anxiety for Japanese learners of English: Preliminary case interviews with five Japanese college students in the USA". TESL-EJ Teaching English as a Second or Foreign Language, 9. http://www.tesl-ej.org/ej35/a3.pdf DW 12.05.2015.

Onwuegbuzie, A.J., Bailey, P. and Daley, C.E. 1997. "Foreign language anxiety among college students". Paper presented at the Annual Meeting of the Mid-South Educational Research Association. Memphis, TN. http://eric.ed.gov/?id=ED415713 DW 12.05.2015.

Piechurska-Kuciel, E. 2008. Language Anxiety in Secondary Grammar School Students. Opole: Wydawnictwo Uniwersytetu Opolskiego. 
Price, M. L. 1991. "The subjective experience of foreign language anxiety: interviews with highly anxious students". (in) Language Anxiety: From Theory and Research to Classroom Implications. (eds. Horwitz, E.K. and Young, D.J.). Upper Saddle River: Prentice Hall: 101-108.

Rogers, A. 2008. Teaching Adults. Berkshire: Open University Press: McGraw-Hill Education. Rogers, J. 2007. Adults Learning. Berkshire: Open University Press: McGraw-Hill Education. Sarason, I. G. 1988. "Anxiety, self-preoccupation and attention". Anxiety Research, 1: 3-7. Seligman, M.E.P., Walker, E.F. and Rosenhan, D.L. 2001. Abnormal Psychology. New York: W.W. Norton and Company.

Scovel, T. 1991. "The effect of affect on foreign language learning: A review of the anxiety literature". (in) Language Anxiety: From Theory and Research to Classroom Implications. (eds. Horwitz, E.K. and Young, D.J.). Upper Saddle River: Prentice Hall: 15-23.

Spielberger, C.D. 1972. Anxiety: Current Trends in Theory and Research. New York: Academic Press.

Spielberger, C.D. 1983. Manual for the State -Trait Anxiety Inventory (STAI -Form Y). Palo Alto, CA: Consulting Psychologists Press.

Studenska, A. 2007. "Foreign language anxiety inventory." The New Educational Review, 11: 241-259.

Turula, A. 2002. "Language anxiety and classroom dynamics: A study of adult learners". English Teaching Forum, 40: 28-37. http://americanenglish.state.gov/files/ae/ resource_files/02-40-2-g.pdf. DW 22.03.2015.

Vasa, R. and Pine, D.S. 2004. "Neurobiology in anxiety disorder in children and adolescents". (in) Anxiety Disorders in Children and Adolescents. (eds. Morris, T.R. and March, J.S.). New York: Guilford Press, 98-121.

Von Worde, R. 2003. "Students' perspectives on foreign language anxiety". http://files. eric.ed.gov/fulltext/EJ876838.pdf. DW 12.05.2012.

Wine, J. 1971. "Test anxiety and direction of attention". Psychological Bulletin, 76: 92-104.

Woodrow, L. 2006. "Anxiety and speaking English as a second language". Regional Language Centre Journal, 37: 308-328.

Young, D.J. 1991. "The relationship between anxiety and foreign language oral proficiency ratings". (in) Language Anxiety: From Theory and Research to Classroom Implications. (eds. Horwitz, E.K. and Young, D.J.). Upper Saddle River: Prentice Hall: 57-63. 